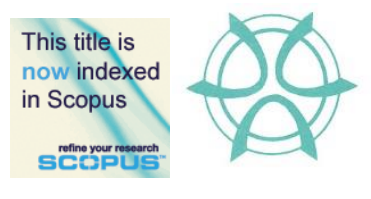

PLANNING MALAYSIA:

Journal of the Malaysian Institute of Planners

VOLUME 17 ISSUE 2 (2019), Page 158 - 167

\title{
ENHANCING THE POTENTIAL OF RECYCLABLES WASTE COLLECTION THROUGH WASTE BANK PROGRAMME: EXPERIENCE FROM HEI IN MALAYSIA
}

\author{
Fatma Sabariah Alias ${ }^{1}$, Latifah Abdul Manaf ${ }^{2}$, Mariani Ariffin ${ }^{3}$, \\ \& Sabrina Ho Abdullah ${ }^{4}$ \\ ${ }^{1,2,3,4}$ Faculty of Environmental Studies \\ UNIVERSITI PUTRA MALAYSIA
}

\begin{abstract}
A voluntary approach for recycling programme can be enhanced by the establishment of waste bank in institutions of higher education. Hence, a waste bank programme was implemented in a "close loop" system at the Faculty of Environmental Studies, Universiti Putra Malaysia (FPAS, UPM). This aims to promote collection of recyclable materials and raise awareness among UPM students on the importance of recycling. Throughout the five (5) phases of operation, about 500 students were registered as waste bank members with the amount of total collected recyclables reaching $14,817.46 \mathrm{~kg}$. The direct measurement method was applied in the waste bank operation procedure to weigh the recyclable materials received twice a week. The most frequent type of recyclable material collected was paper, including black/white paper, newspaper, and mix paper. The waste bank programme has enhanced the potential of solid waste minimisation by shifting the amount of waste disposed at the landfill site. Moreover, it enables recyclable materials to be seen as valuable resources as monetary rewards were given to encourage recycling practices among students based on the total weight for each collection of recyclable materials. Therefore, the implementation of the waste bank programme in Higher Education Institutions (HEI) in Malaysia creates an opportunity to be a medium of a sustainable solid waste minimisation system in promoting sustainable green campuses at the university.
\end{abstract}

Keywords: awareness, green campus, higher education institution, recyclables, recycling, waste bank 
PLANNING MALAYSIA

Journal of the Malaysia Institute of Planners (2019)

\section{INTRODUCTION}

The rapid rate of development in Malaysia has accelerated the daily generation and volume of solid waste. The amount of waste produced has increased from 33,000 tonnes in 2012 to 38,000 tonnes of waste in year 2015. This figure is expected to increase to 16.76 million tonnes by year 2020 with 45,900 tonnes of waste are predicted to be generated every day (Agamuthu \& Dennis, 2011; SWCorp. 2012; SWCorp, 2014). Approximately $28 \%$ of the total daily waste generated originate from the commercial and institutional sectors, which contributed 9,224 million tonnes of waste generated daily (NSWMD, 2015).

At the same time, the rapid expansion of the Higher Education Institutions (HEI) sector in Malaysia has also led to the increasing of solid waste generation as the population within HEIs in Malaysia increases (Jibril, Sipan, \& Lawal, 2012). Population in HEIs comprises administrative personnel, students, academic staff and non-academic staff. These groups produced waste of which only $40 \%$ of recyclable items were collected at educational institutions with an average per person of $0.33 \mathrm{~kg} /$ person/day. Additionally, the recycling rate for the institutional and commercial sectors is about $7.4 \%$ and almost $89 \%$ of waste were disposed of in landfill sites (NSWMD, 2015).

A recycling programme is an activity which often attracts attention in HEIs as an on-going sustainability initiative for solid waste management. HEIs are among the major contributors to the increase in solid waste generation and most of the waste generated were recyclable materials (Kehmeyer et al., 2011). HEIs in Malaysia have taken the initiative to implement recycling as a campus sustainability programme by involving the campus community, such as in Universiti Sains Malaysia (USM). However, the recycling programme failed to achieve sustainability due to the seasonal nature of the programme and the ineffective recycling system adopted (Abas \& Md Nor, 2014). Meanwhile, Universiti Teknologi Malaysia (UTM) has produced the UTM Sustainable Campus Policy as a general guideline for campus sustainability including areas such as energy management. Monday is UTM Recycling Day, where the Green Office and Sustainable Arcade make an effort to provide a conducive campus environment for a sustainable learning and teaching environment in the university (Zen, Ahamad, \& Omar, 2014). UPM was also the leading university in terms of sustainable campus by implementing the Environmental Management System (EMS) MS ISO 14001 through activities relating to the teaching and learning process in the campus towards sustainable development goals.

In fact, solid waste minimisation strategies (particularly in recycling) have been noted as practical solutions in overcoming the solid waste disposal issues due to the increasing waste generation rates (Sakawi, 2011). Moreover, Purcell and Magette (2010) also revealed that recycling can reduce the waste disposal problem by extending the landfill space and prolonging the lifespan of landfill sites. 
Fatma Sabariah Alias, Latifah Abdul Manaf, Mariani Ariffin, \& Sabrina Ho Abdullah,

Enhancing the Potential of Recyclables Waste Collection Through Waste Bank Programme: Experience from Higher Education Institutions in Malaysia

Initially, recycling collections were dominated by the informal sector such as door-to door itinerant recycling buyers, waste collection workers separating recyclable materials and scavenging activities in landfills (Siwar, 2008). Zen and Siwar (2015) revealed that about $31 \%$ of households have a high preference towards door-to-door itinerant buyers because of monetary incentives received. Besides that, accessibility of kerbside recycling and drop-off recycling has a significant impact on solid waste reduction and can also have a positive effect on the percentage of recyclables collected. However, both methods largely dependent on household participation on voluntary basis. Nevertheless, the individuals' recycling participation is also influenced by investment of time, space, money and effort, in addition to their knowledge and attitude towards recycling (Sidique, Joshi, \& Lupi, 2010).

According to Beringer, Wright and Malone (2008), and Zen, Bandi, Zakaria and Saleh (2013), campus waste characterisation studies are relatively inexpensive and can generate administrative support and cooperation among students and academia by inspiring involvement in the sustainable campus community. This can be achieved through activities involving the aspects of teaching, learning and research as part of the education to the campus community. Thus, this paper highlights the activities of UPM through its Faculty of Environmental Studies' initiative of implementing a waste bank programme for the campus community as part of its ongoing efforts to promote green campus.

\section{RESEARCH BACKGROUND}

Universiti Putra Malaysia (UPM) formerly known as Universiti Pertanian Malaysia is located in Serdang, Selangor next to Malaysia's administrative capital city, Putrajaya. It is one of Malaysia's leading research universities (RU) with a total enrolment of 24,874 students and 2,595 academic staff for the 2016 academic year. Its campus sits on an estimated 1,108.103 hectares of land, housing 16 faculties, 17 student hostels, nine (9) institutes, four (4) centres and several administrative and academic buildings respectively. The major activities on campus focused on teaching, research and extracurricular activities such as sports, recreation, associations, clubs, arts and culture.

\section{Waste Bank Initiative}

The waste bank was initiated by a lecturer in FPAS and a group of volunteers from the solid waste management course (EMG 3104). They were inspired by UPM's green campus aspiration and sought to achieve this by reducing solid waste generation and promoting recycling practices among the campus community. The project began in the year 2015 and has continuously being operated on the campus. The waste bank (Figure 1) is located at the Solid Waste Lab at FPAS, UPM. 


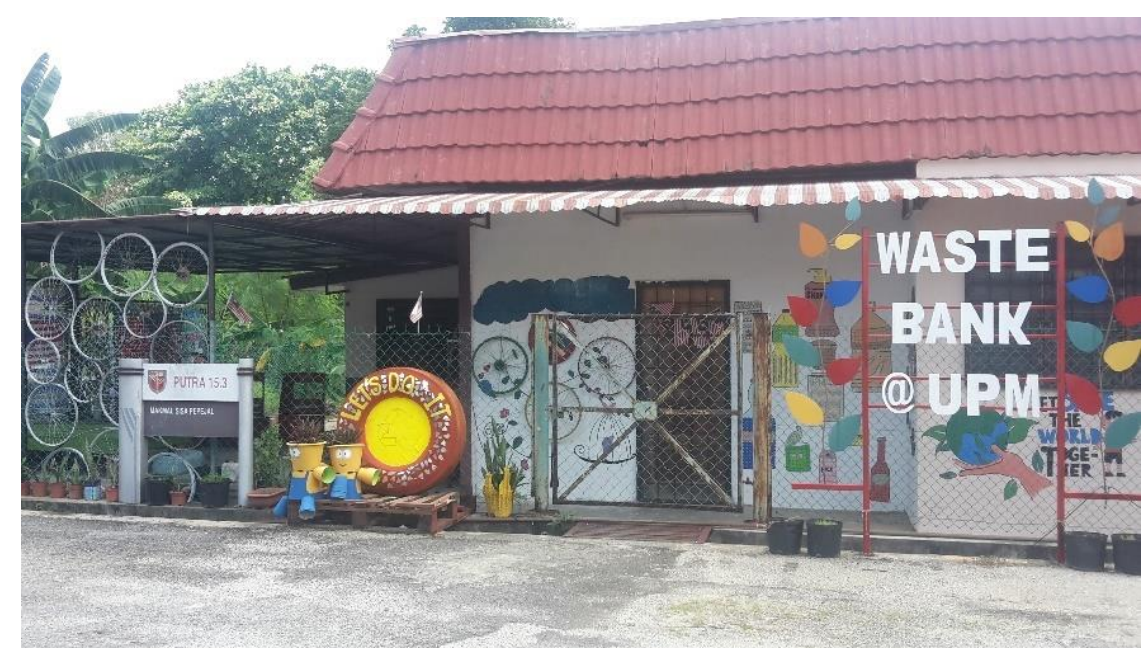

Figure 1 Waste bank at Faculty of Environmental Studies, UPM

\section{Waste Bank Operation Procedure}

The waste bank operates twice a week during 14 weeks of teaching and learning in campus for every semester. It began its operation on October 2015 and has been continually operated every semester since then. Figure 2 shows the operational procedure, which has been implemented in the waste bank programme. There are four main steps, namely, registration, sorting, weighing, and recording. Firstly, students have to register as waste bank member where each member will receive a waste bank book. Recyclable waste brought by students to the waste bank will then be sorted and stored at the waste bank. Next, the recyclable waste will be weighed by direct measurement method based on the recyclable waste category and recorded in the waste bank book. The sampling guideline was based on the Malaysian Standard guideline for solid waste generation and composition (Department of Standard Malaysia, 2012). The type of recyclable waste and total weight will be recorded to ensure that the amount of recyclable waste per kilogram is calculated correctly. At the end of semester, as a way of encouraging recycling practices at UPM, the waste bank members received monetary incentives, university merits and rewards based on their participation in the waste bank programme. 
Fatma Sabariah Alias, Latifah Abdul Manaf, Mariani Ariffin, \& Sabrina Ho Abdullah,

Enhancing the Potential of Recyclables Waste Collection Through Waste Bank Programme: Experience from Higher Education Institutions in Malaysia
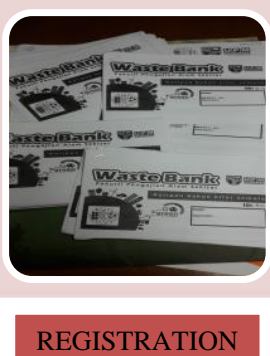

-Each participants registers and

receive a waste

bank book

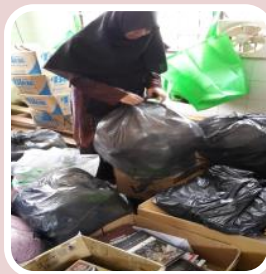

SORTING

-The operator sorts the waste

according to each category
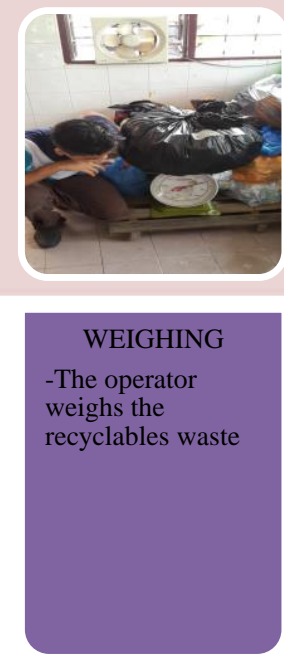

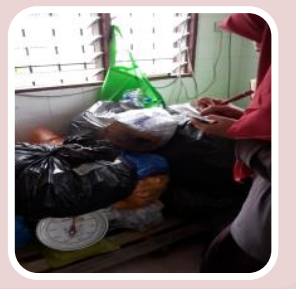

RECORD

- The operator records the weight into the waste bank book

Figure 2 Waste Bank Operation Procedure

\section{Type of Recyclable Waste}

The waste bank receives five (5) main types of recyclable waste namely:

i. Paper: Newspaper, Mix paper, Black/white paper;

ii. Plastic: PETE, HDPE;

iii. Aluminium cans: Can drinks;

iv. Box/cardboard: All types of boxes; and

v. Metal: Food cans and all types of metal.

\section{RESULTS AND DISCUSSION}

Waste bank has been operating in a five (5) phase operation where about 500 students had registered as waste bank members since October 2015 until December 2017, with the total recyclables collection reached $14,817.46 \mathrm{~kg}$ (Table 1). The participation in the waste bank has been on a voluntary basis among UPM students and a mandatory basis for environmental students who took the Solid Waste Management Course (EMG 3104) as part of their teaching and learning process.

Table 1 Waste bank recyclables collection

\begin{tabular}{|c|c|c|c|}
\hline Phases & Time & $\begin{array}{c}\text { Member } \\
\text { (nos.) }\end{array}$ & Recyclables collection $(\mathrm{kg})$ \\
\hline 1 & October-December 2015 & 53 & $1,663.22$ \\
\hline 2 & March-June 2016 & 113 & $1,986.11$ \\
\hline 3 & October-December 2016 & 137 & $3,604.74$ \\
\hline 4 & March-June 2017 & 144 & $5,555.74$ \\
\hline \multirow[t]{2}{*}{5} & October-December 2017 & 53 & $2,007.65$ \\
\hline & TOTAL & 500 & $14,817.46$ \\
\hline
\end{tabular}


PLANNING MALAYSIA

Journal of the Malaysia Institute of Planners (2019)

Phase 1 was the pilot phase where 53 students who took the Solid Waste Management Course (EMG 3104) were required to be involved in collecting recyclable waste as part of their teaching and learning process in the faculty. Saphores, Ogunseitanc and Shapiro (2012) stated that there is a positive correlation between knowledge and action in environmental behaviour. Thus, the students managed to collect $1,663.22 \mathrm{~kg}$ of recyclable materials in 14 weeks. The overwhelming results encouraged the waste bank programme to be continually operated for the next phase.

In Phase 2, waste bank operation was opened to UPM students and staff on a voluntary basis in which increasing amount of recyclables were collected. About $1,986.11 \mathrm{~kg}$ of recyclable waste was collected showing the increased awareness towards recycling. Subsequently, to also support the university effort towards green campus, several activities and recycling programmes were organised during Phases 3 and 4. The amount of recyclables collected, again, increased due to overwhelming participation from the students in the campus. National Recycling Day, Waste Bank Open Day and Recycling Training were organised in FPAS to raise awareness on the importance of recycling. Besides that, as part of the teaching and learning process in EMG 3104, the environmental students were required to spread recycling awareness in every faculty in the UPM campus and promote the waste bank programme. The increasing participation has increased the amount of recyclables collection from $3,604.74 \mathrm{~kg}$ to $5,555.74 \mathrm{~kg}$.

In addition, to encourage recycling practices among UPM students, monetary incentives were provided to each member as well as university merit as a reward for their participation. However, in phase 5, which extended from October until December 2017, the amount of recyclables collected decreased to $2,007.65 \mathrm{~kg}$. The reduced amount could possibly be due to other recycling collections being operated in other faculties, due to growing awareness towards the idea of a green campus for a sustainable community. Furthermore, recycling awareness has increased among campus community as UPM has conceived a Green Policy. The Green Policy also has recognised the waste bank programme as part of the green activities in the campus. The existence of waste bank as a positive asset of the university in encouraging students to participate actively in recycling practices on campus supports Dahle and Neumayer's (2001) research where they proposed that HEIs can serve as a role model in environmental behaviour by implementing an appropriate recycling system on campus.

Figure 3 shows the total weight and total sales for each type of recyclable waste collected at the waste bank. The highest type of recyclable waste collected was paper; $8,453.26 \mathrm{~kg}$. This is followed with plastic waste collection figures reaching $2,124.72 \mathrm{~kg}$, together with other types of recyclable waste such as box/cardboard $(1,977.45 \mathrm{~kg})$, aluminium cans $(1,153.68 \mathrm{~kg})$, and metal $(1,108.35 \mathrm{~kg})$. Based on the price of recyclables in waste bank, aluminium cans represent the highest total sales (RM2,307.36). This is followed by plastic. For 
Fatma Sabariah Alias, Latifah Abdul Manaf, Mariani Ariffin, \& Sabrina Ho Abdullah,

Enhancing the Potential of Recyclables Waste Collection Through Waste Bank Programme: Experience from Higher Education Institutions in Malaysia

paper, black paper and white paper have higher sales compared to mix paper and newspaper despite lower amount collected. The high sales show that recyclable materials have high potential in market values as well as economic benefits.

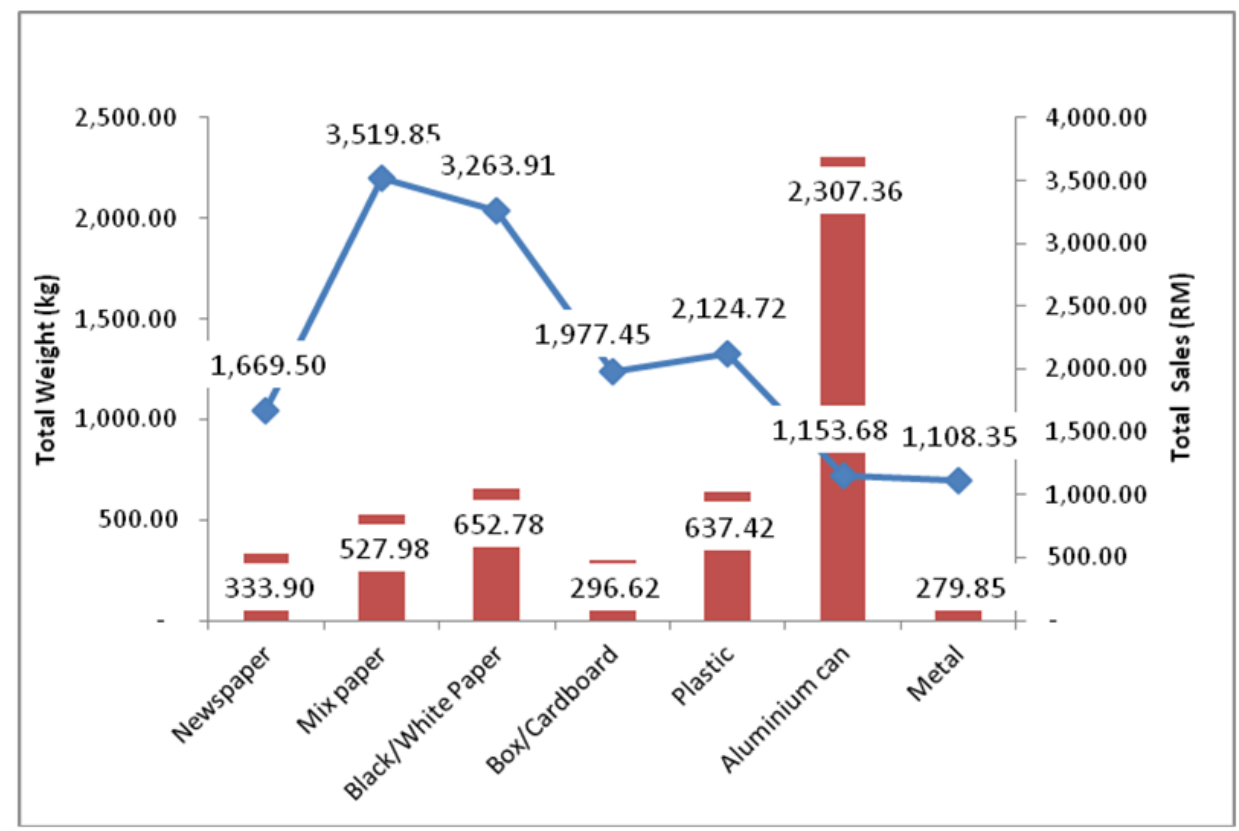

Figure 3 Total weight and total sales of recyclable waste by category

Table 2 shows that the potential waste bank revenues from the recyclables collection reached RM7,182.96 based on the market price set by Alam Flora Sdn Bhd. The amount indicates that collection of recyclables has a high potential value in market sales as the potential margin profit reached RM2,147.05 with an average of RM 429.41 collected each phase. Normally, due to the fluctuating price of recyclables in the market, demand has prompted the waste bank operator to update the price of recyclable materials in the waste bank during the waste bank operation. Although some of the prices of recyclables were low, it did not become a barrier to students from participating in the waste bank programme, as awareness generated from the recycling process is more important. 
PLANNING MALAYSIA

Journal of the Malaysia Institute of Planners (2019)

Table 2 Waste Bank Potential Revenues

\begin{tabular}{|c|c|c|c|c|}
\hline \multirow[t]{2}{*}{ Items } & \multirow{2}{*}{$\begin{array}{l}\text { Recyclable } \\
\text { Collection }(\mathrm{kg})\end{array}$} & Recyclables & \multirow{2}{*}{$\begin{array}{l}\text { Total Sales in } \\
\text { Waste Bank } \\
\text { (RM) }\end{array}$} & \multirow{2}{*}{$\begin{array}{l}\text { Potential } \\
\text { Revenues } \\
(\mathrm{RM})\end{array}$} \\
\hline & & $\begin{array}{l}\text { Market Price } \\
(\mathrm{RM})^{*}\end{array}$ & & \\
\hline Newspaper & $1,669.50$ & 0.24 & 333.90 & 400.68 \\
\hline Mix paper & $3,519.85$ & 0.18 & 527.98 & 633.57 \\
\hline $\begin{array}{l}\text { Black/White } \\
\text { paper }\end{array}$ & $3,263.91$ & 0.34 & 652.78 & 1109.79 \\
\hline Plastic & $2,124.72$ & 0.40 & 637.42 & 849.88 \\
\hline Aluminium & $1,153.68$ & 3.00 & 2307.36 & 3461.04 \\
\hline Box/Cardboard & $1,977.45$ & 0.20 & 296.62 & 395.49 \\
\hline Metal & $1,108.35$ & 0.30 & 279.85 & 332.51 \\
\hline Total & $14,817.46$ & & $5,035.90$ & $7,182.96$ \\
\hline
\end{tabular}

Figure 4 shows that $57 \%$ of the recyclable waste collection consisted of paper (newspaper/mix paper and black/white paper). This represented the highest quantity of recyclable waste collected. This is due to the location of waste bank at Universiti Putra Malaysia (UPM), one of the HEIs in Malaysia which influenced the type of recyclable waste in the collection. Moreover, the campus activities of teaching and learning produce a significant amount of recyclable waste paper such as lecture notes, books, study notes, exam papers, letters, memos and research papers. Plastic waste also provided good revenue for the recycling programme as there was $14 \%$ of plastic material collected in the waste bank. The plastic waste consisted of plastic code 1 which is PETE and mineral bottles, and plastic code 2: HDPE such as shampoo, liquid soap bottles, and cosmetic containers. The collection also comprised aluminium cans including those from carbonated drinks, and metal consisting of food cans and all types of metal.

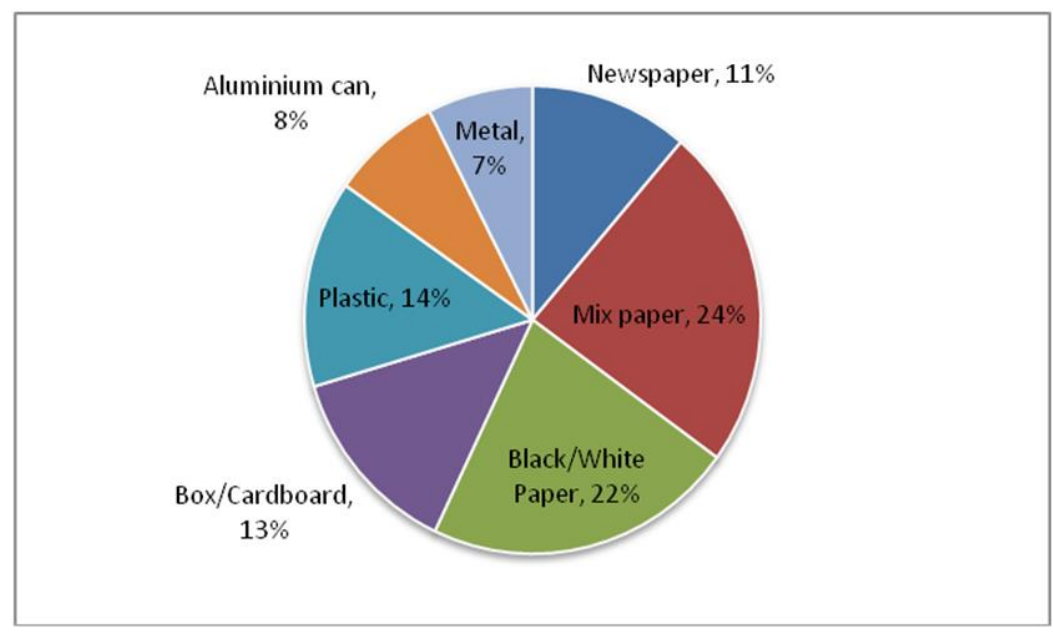

Figure 4 Percentage of recyclable waste by category 
Fatma Sabariah Alias, Latifah Abdul Manaf, Mariani Ariffin, \& Sabrina Ho Abdullah,

Enhancing the Potential of Recyclables Waste Collection Through Waste Bank Programme: Experience from Higher Education Institutions in Malaysia

Throughout the waste bank operation, monetary rewards and university merit were an encouragement for students to participation. These have also become a key contributing factor to the success of the waste bank operation in UPM. Basri, Zawawi, Zain, Mohamad and Kasa (2016) also mentioned that encouragement and incentive measures should be provided to students as this will motivate them to be more keen to participate in the on-campus recycling activities. Students play a vital role in the sustainable campus society as their attitudes and behaviour have been of great importance in the success of the recycling programme.

\section{CONCLUSION}

Based on the results obtained, it can be concluded that it is important to develop sustainability policies in campus which cover the issue of solid waste minimisation to support the waste bank programme. The waste bank programme reveals the potential of solid waste minimisation, as can be seen from the recyclables collection in the campus and also raised awareness towards the importance of recycling. Besides that, the waste bank programme also shows the potential value of recyclables in the market. Moreover, it could be suggested that the waste bank programme can be seen as an environmental protection in HEIs as part of the learning and teaching programme aiming towards sustainability of campuses and green universities. A waste bank programme would be a beneficial model for a sustainable solid waste minimization system for HEIs in Malaysia in order to increase awareness levels towards sustainability development goals.

\section{ACKNOWLEDGEMENT}

The authors would like to thank the volunteers and participants at Universiti Putra Malaysia (UPM) for their time and support of the waste bank programme at the Faculty of Environmental Studies.

\section{REFERENCES}

Agamuthu, P., \& Dennis, V. (2011). Policy trends of extended producer responsibility (EPR) in Malaysia. Waste Management \& Research Journal. Retrieved from https://www.researchgate.net/publication/51504774_Policy_trends_of_extende d_producer_responsibility_in_Malaysia.

Abas, M. A., \& Md Nor, N. (2014). Participation of campus community at Universiti Sains Malaysia on the single stream recycling system. Jurnal Personalia Pelajar, 17, (83-95).

Basri, N. E. A., Zawawi, M. A., Zain, S. M., Mohamad, W. N. A. W., \& Kasa A. (2016). Effects of an awareness programme on the perception of engineering students at the Universiti Kebangsaan Malaysia towards solid waste recycling practices. Pertanika Journal of Social Science and Humanities, 24, 1-14. 
Beringer, A., Wright, T., \& Malone, L. (2008). Sustainability in higher education in Atlantic Canada. International Journal of Sustainability in Higher Education, 9(1), 48-67.

Dahle, M., \& Neumayer, E. (2001). Overcoming barriers to campus greening: A survey among higher educational institutions in London, UK International Journal of Sustainability in Higher Education, 2, 139-160.

Department of Standard Malaysia (2012) MS 2505:2012, Malaysian Standard. Guideline for sampling of household solid waste - Composition and Characterisation analysis. Kuala Lumpur: Author.

Jibril, J, Sipan, I., \& Lawal, J. (2012). 3R's critical success factor for integrated solid waste management in higher educational institution. International Journal of Sustainable Development, 05(10), 109-120.

Kehmeyer, M., Miller, C., Neppel, K., Ronnebaum, C., Webber, J. \& Zinke, B. (2011). Waste characterization study for Kansas State University Recycling. Kansas State University, Natural Resources and Environment Sciences Capstone Course.

National Solid Waste Management Department [NSWMD], (2015). Final Lab Report, Solid Waste Management Lab 2015. Ministry of Housing and Local Government (MHLG)

Purcell, M., \& Magette W. L. (2010). Attitudes and behaviour towards waste management in the Dublin, Ireland region. Waste Management, 30, 1997-2006.

Saphores, J. M., Ogunseitanc, O. A., \& Shapiro, A. A. (2012). Willingness to engage in a pro-environmental behavior: An analysis of e-waste recycling based on a national survey of U.S. households. Resources, Conservation and Recycling, 60, 49-63.

SWCorp, (2012). Composition on household solid waste in Malaysia. Final report survey on solid waste composition, characteristic, and existing practice of solid waste recycling in Malaysia.

SWcorp. (2014). Pelan Strategik Swcorp 2014-2020, Melakar Dimensi Baharu Menuju Masa Hadapan.

Sakawi. Z., (2011). Municipal solid waste management in Malaysia: Solution for sustainable waste management. Journal of Applied Sciences in Environmental Sanitation, 6(1), 29-38.

Siwar, C. (2008). Solid waste management: Recycling, green jobs and challenges in Malaysia. ILO Research Conference on Green Jobs for Asia \& Pacific. April 2123, 2019, Niigata, Japan.

Sidique, S. F., Joshi, S. V., \& Lupi, F. (2010). Factors influencing the rate of recycling: An analysis of Minnesota counties. Resources, Conservation and Recycling 54, 242-249.

Zen, I. S. \& Siwar, C. (2015). An analysis of household acceptance of curbside recycling scheme in Kuala Lumpur, Malaysia. Habitat International, 47, 248-255.

Zen, I. S., Ahamad, R., \& Omar, W. (2014). The development and measurement of conducive campus environment for Universiti Teknologi Malaysia (UTM) of campus sustainability. Jurnal Teknologi, 68(1), 71-82

Received: $12^{\text {th }}$ January 2019. Accepted: $2^{\text {nd }}$ August 2019 